will be run as boarding-schools and will provide education for the eldest sons and daughters of native chiefs in the two colonies. The course planned will comprise $s$ years' study in the Colony, followed by a short stay in Portugal. Each eldest son and heir will be educated along with two other members of his tribe who will be his future councillors. The programme of studies includes instruction in Portuguese, in local geography, administrative practice and police duties, agricultural practice and improvement, road construction, hygiene, and treatment of tropical diseases.

\title{
Colonial University Development
}

Ar the sixth congress of the Universities of the Commonwealth, held at Oxford in July 1948, a day was devoted to a consideration of plans for Colonial Higher Education and to the extension of the University Secondment Scheme. The problems discussed included finance, relations with colonial governments, consultation of local opinion in planning Colonial Universities, the building up of libraries, the need for a system of interchangeability with United Kingdom and other Commonwealth Universities, and the importance of providing a standard of teaching and research comparable with United Kingdom standards.

In regard to Africa, progress has been made in the direction of providing higher education. The site for the new University College at Ibadan has been selected and surveyed, the Principal and some of the staff have been appointed, and the College was opened in January 1948 in temporary buildings; the new University College in the Gold Coast is also working in temporary buildings, the Principal has been appointed, and certain courses are at present being given at Achimota College. In East Africa Makerere College is being developed as the future University of East Africa.

\section{Colonial Surveys}

THE Department of Colonial (Geodetic and Topographical) Surveys of the British Colonial Office, which was formed in 1946 , is engaged on the production of large-scale maps of Colonial territories. The maps are made from aerial photographs, taken by mean sof radarcontrolled air-photography; the photographs are annotated by ground survey parties before being dispatched to England where a staff of technicians is engaged in preparing the maps. Maps have already been prepared for the Volta River delta, Gold Coast (scale I : 5,000 ), groundnut areas in Tanganyika (scale I : 50,000 ), Gambia colony (scale I : 50,000 ), Freetown Peninsula of Sierra Leone (scale $I: 10,000$ ). In addition programmes of air photography have been worked out for areas in Kenya, Uganda, N. Rhodesia, Nyasaland, Swaziland, Bechuanaland, Nigeria, Gold Coast, Sierra Leone.

\section{Présence Africaine}

A MONT'HLY journal, of which the first four numbers have been received, is being published in Paris, under the direction of M. Alioune Diop and an editorial committee composed of French and African members. The paper is primarily concerned with literature and the arts, but carries also articles on race relations, psychology, sociology, and language. Each number contains original prose and verse in French by African authors.

\section{Training African Artisans}

DURING its three years of existence the training centre for African ex-service men at Kabete, Nairobi, has passed out some 1,400 Africans after completion of a training course of 6 
months; a further 800 are receiving training as bricklayers, masons, carpenters, plumbers, fitters, welders, electricians, decorators, turners, tailors, shoemakers, and motor mechanics. In spite of the shortness of the period of training, general satisfaction with the competence of the trainees has been expressed by employers. The government electrical engineer has accepted 50 men in the last 6 months; these constitute half the non-European staff of his department. At the centre there is one European supervisor to so trainees and one African instructor to every I5. As a training school of ex-servicemen, the school is due to end its career in December 1948, but plans have been formulated to establish it as a permanent college for adult African students.

\section{Thomas Mofolo}

Thomas Mofolo, the author of Chaka and other notable books, died on 8 September 1948 at his home at Teyateyaneng in Basutoland, after a long period of ill health. The second son of Christian Basuto he was born at Khojane, in the Mafeteng district, in August 1877 but spent most of his boyhood at Qomoqong in the more southern district of Quthing. His life as a herd-boy in that region of imposing mountains and fertile valleys left a lasting impression upon his mind and is reflected in his books which, incidentally, disprove the often asserted statement that the African has no eye for beauty. He attended a village school superintended by the Rev. Lechesa Segoete (another name that figures in Sotho literature), one of the native pastors, and at the age of twenty entered the Mission school at Masitisi. Thence in 1894 he went to continue his education at Morija, the central station of the Paris Evangelical Society, where after a course at the Bible School he was enrolled in the Normal School and passed out with the teachers' certificate in 1899 . It was at that time, when teaching at Morija, I met him first and little thought that one of my students would make a name as a writer. He worked as proof-reader in the Morija Book Depot until this closed down for a time in consequence of the South African War; taught in a school at Maseru until the end of the war and then returned to the Book Depot. In 1910 he went to the institution at Leloaleng to teach and to learn carpentry. Thereafter he took a spell at mining in Johannesburg and later engaged in recruiting labour for the mines, at first as agent of the Eckstein group of mines and afterwards as a free-lance. His next experiment in life was to open a trading-store at Bokong in the mountains of Basutoland. This was in 1928 and the business, together with a mill which he had started at Teyateyaneng as early as 1916 , occupied most of his time until ill health forced him to leave his native land. He bought a farm in the Matatiele district of the Union but found difficulty in running it under conditions imposed by the Land Acts and returned to his home, where he remained, always a sick man, until his death.

He began his literary efforts while engaged at the Morija Book Depot, and his first book appeared in serial form in the Mission newspaper, Leselinyana. It was later published in book form with the title Moeti oa Bochabela, and translated by $\mathrm{H}$. Ashton into English as The Traveller of the East (S.P.C.K.). More appropriately it should be entitled $A$ Traveller to the East, for it tells how a MoSotho of olden time set out on a quest to the East in search of the legendary Ntsoanatsatsi (the original home of his people) and Molimo, the God of whom his fathers spoke. Fekisi, the hero, reminds one of the Buddhist lama in Kim and his search for the river; and of the old MoSotho of whom Eugene Casalis writes, who sought for a solution of the enigma of this universe. Mofolo's second book, Pitseng, has not, so far as I am aware, been put into English. It is a novel on more familiar lines and is written in what all BaSotho say is the most charming Sotho.

It is chiefly on his historical romance Chaka that Mofolo's fame rests. This was written after careful study of the traditional accounts of the Zulu king and conqueror, but is no mere chronicle. It was translated into English by F. H. Dutton, Director of Education, and 